\title{
THE ENTREPRENEURSHIP ECOSYSTEM IN MALAYSIA: THE GLOBAL ENTREPRENEURSHIP INDEX (GEI) ANALYSIS
}

\author{
SAKTI HENDRA PRAMUdYA ${ }^{1}$ \\ University of Pécs (Hungary), Binus University (Indonesia)
}

\begin{abstract}
The purpose of this research is to identify the entrepreneurship ecosystem in Malaysia based on PFP methodology from the Global Entrepreneurship Index (GEI). As one of the top performing economies in Asia, the Global Entrepreneurship Index (GEI) score of Malaysia stood in the 'middle rank' from 2012 to 2016 (ranked 46th out of 96 surveyed countries). The analysis has revealed that Malaysia has two strong pillars that are unique to the country, namely 'human capital' and 'process innovation'. There are seven other pillars that did not perform well, namely, technology absorption pillar, high growth, risk capital, cultural support, product innovation, start-up skills, and internationalisation. In order to improve these areas, the Malaysian government needs to enact 'supportive regulation' for entrepreneurs, such as promoting entrepreneurs in external events, tax holidays, a less complicated business permit application process, ease of access to bank loans, and business training.

KEY WORDS: entrepreneurship ecosystem, GEI, Malaysia.
\end{abstract}

JEL CODES: L26, O38, R11.

DOI: https://doi.org/10.15181/rfds.v35i3.2273

\section{Introduction}

As one of the fast-growing economies in the southeast Asia region, Malaysia has set itself on a path to becoming a developed country in 2020 (Khan, Liew, Ghazali, 2014). As of 2016, Malaysia's GDP was the fifth largest in ASEAN (Association of South East Asian Nations). The largest contributor to Malaysia's GDP is from the service sector (wholesale and retail trade, information and communication, and finance and insurance) with a share of 54.5\%, followed by the manufacturing sector (electronic, petroleum, chemical, rubber and plastic products) with a share of $23 \%$, and the mining sector (mostly oil and gas mining activities) with a share of $8.4 \%$ (Department of Statistics, Malaysia, 2018). The economy of Malaysia is also one of the most competitive in the world. According to the Global Competitiveness Report 2017, Malaysia's economy is the 23rd most competitive in the world (World Economic Forum, 2018). Malaysia could be considered a prosperous country, with a relatively high income per capita of USD 10,620 (nominal) in 2017; thus, it is the third wealthiest country in southeast Asia, behind Singapore and Brunei (International Monetary Fund, 2017). Hence, it can be concluded that Malaysia is one of the few countries in the world with excellent financial conditions for supporting entrepreneurship.

Despite the strong macroeconomic performance, the recent economic situation of Malaysia has been disrupted by internal political turmoil. The political struggle between the Barisan Nasional ruling coalition parties and the opposition coalition parties of Pakatan Harapan resulted in the total defeat of Barisan Nasional, which led to major economic policy reforms. The ousted prime minister Najib Razak from Barisan Nasional is currently facing allegations from 1 Malaysia Development Berhad (1MDB) about a mega-

Sakti Hendra Pramudya - PhD student in the Faculty of Business and Economics, University of Pécs, Hungary

Scientific interests: family business, entrepreneurship, and marketing research

E-mail: saktihendrapramudya@gmail.com

Tel. +36204132632 / +6281297357 784 
corruption scandal (USD 4.5 billion), which Pakatan Harapan claims affected the stability of Malaysia's economy (Hazis, 2018). The new prime minister of Malaysia, Mahathir Mohamad (the oldest world leader to take office, at the age of 92), is conducting a series of populist economic reforms, such as abolishing the goods and services tax $(6 \%)$, providing numerous generous government subsidies to Malaysian citizens, and introducing a new economic policy (Pennington, 2019). The new government, in turn, is also prioritising the development of entrepreneurship as one of their primary policies for economic reform. The new government is reviving the Ministry of Entrepreneur Development, after its closure in 2007, with the aim of providing training for entrepreneurs, and also as a coordinating body for related agencies to strengthen the contribution of entrepreneurial activities to the economy (Bernama, 2018). However, the problem that exists relating to entrepreneurial development in the country is related to ecosystem mapping (environments, opportunity and growth), which would be beneficial as a tool to compare with other countries (Ahmad, Xavier, 2012). For example, comparing the number of entrepreneurs between countries alone will not reflect the 'quality' of their business, such as the skills they have, technology absorption, and human capital. Hence, when we have a set of categories (in GEI, it is called 'pillars') that are clearly defined (under the entrepreneurship ecosystem framework), the comparison will provide more 'meaningful' insights, by 'zooming in' to a particular criterion. Based on the previously mentioned premise, the purpose of this paper is to identify Malaysia's 14 pillars of GEI, to determine its position among other countries in the southeast Asia region, while providing suggestions to increase the score of low-score pillars through a GEI policy package to help the Malaysian government determine the best entrepreneurship-related policy, which is critically needed by the Malaysian government (Ariffin, Baqutayan, Mahdzir, 2020). The subject of the research is Malaysian entrepreneurs that provided responses to the GEI global survey from 2006 to 2016 to measure Malaysia's 14 pillars of GEI. The main task of this paper is to analyse the entrepreneurship ecosystem of Malaysia through the 14 pillars of GEI, while comparing it with other countries based on GEI data from 2006 to 2016, with the research objectives as follows:

- To analyse the GEI score of Malaysia.

- To measure the GEI performance of Malaysia.

- To suggest a GEI policy package for Malaysia.

The paper uses the descriptive statistics method by conducting a time series analysis of GEI data, re-calculating and re-displaying the data based on its sub-indices, as well as a score comparison between countries in the southeast Asia region.

\section{Literature}

The development of entrepreneurship in Malaysia is rooted in trading activities that were conducted by various ethnic groups in the region, which gradually developed into large-scale industrialisation. After gaining independence from the British Empire, the new government of Malaysia exerted minimum intervention towards industry, and left the sector entirely to be developed by private enterprise; hence, it stimulates entrepreneurial activities in the country with the main purpose of undertaking a significant proportion of industrial projects (Abdullah, Muhammad, 2008). However, ethnic Chinese Malaysian entrepreneurs were overly dominated by other ethnic groups in undertaking projects.

During the next few decades, government intervention in entrepreneurial activities grew stronger. This era is also known as the New Economic Policy (NEP) era, which lasted from 1971 to 1991. The main purpose of the NEP was to eradicate the imbalance of racial economics between the majority native Malay people and Chinese Malaysians (the majority of Malaysian businesses at the time were controlled by Chinese Malaysian entrepreneurs). As a milestone of government support to Malay entrepreneurs, the Malaysian government established the Bumiputra Commercial and Industrial Community (BCIC) as an organisation to nurture ethnic Malay entrepreneurs. It hoped that in the next 20 years, Malay people would own and control $30 \%$ of all industrial and commercial sectors in Malaysia, displacing the domination of Chinese Malaysian 
entrepreneurs (Hamidon, 2014). In addition, the government also established the Ministry of Entrepreneur Development (MED), to assist the government in achieving 30\% native Malay shareholdings in all industries by 2020, and accelerating the development of the BCIC. Under the guidance of the MED and BCIC, ethnic Malay entrepreneurs enjoy generous support from the government (numerous incentives, and even government contracts), as well as indirectly benefitting from the liberal economic policy, which attracts foreign investment (Abdul, Fazilah, 2002).

Even though numerous efforts have been made to nurture Malaysian entrepreneurs, Chinese Malaysian entrepreneurs still dominate key industries and own more businesses than native Malays, and ironically, the economic development of Malaysia has created abundant employment opportunities, which in turn have attracted ethnic Malays to work as professionals rather than establishing their own businesses (Hamidon, 2014). Despite this failure, the numbers of entrepreneurs and their enterprises have steadily increased. The number of entrepreneurs in the country increased from $18.5 \%$ in 2002 to $20.9 \%$ in 2008 , with the majority of them coming from a relatively old age group (35 to 64 years old), who engage in the agricultural sector (Department of Statistics Malaysia, 2009). Besides, based on the more recent 2016 economic census, the number of establishments (enterprises) has significantly increased, from 662,939 in 2011 to 903,818 in 2015, with a $6.4 \%$ growth rate per annum. The top three contributors to the establishments are the services sector $(88.5 \%)$, the manufacturing sector (5.43\%), and the construction sector (4.49\%) (Department of Statistics Malaysia, 2018). This data illustrates a subset of a more complex entrepreneurship ecosystem in the country.

The entrepreneurship ecosystem is a complex set of actors, networks, institutions and values, which produce and sustain entrepreneurial activities (Roundy, Bradshaw, Brockman, 2018). The entrepreneurial ecosystem is a manifestation of the concept of the system of entrepreneurship, and this concept is based on three important aspects, which served as an analytical platform for the analysis of the entrepreneurial ecosystem. Firstly, entrepreneurship is, essentially, an action which is conducted and driven by agents on the basis of incentives. Secondly, the action of an individual is affected by the institutional framework. And thirdly, the entrepreneurship ecosystem is a very complex, multi-layered structure, whereas the elements may interact to create systems performance (Ács, Szerb, Lloyd, 2017). Isenberg (2011) also illustrates the complexity of the concept by stating that there are six important domains of the entrepreneurship ecosystem (human capital, markets, policy, finance, culture and support), which contain 12 core components.

Xavier, Clayton, Yusof, Nor and Sapuan (2014) provided a comprehensive explanation of the latest entrepreneurial ecosystem situation in Malaysia based on GEM (Global Entrepreneur Monitor) data. According to them, access to the physical infrastructure, entrepreneurship opportunity for start-ups, and the entrepreneur's social image, are the dominant components which stimulate entrepreneurial activity. The economic development of the country has created a 'trickle-down effect' for the creation of a reliable physical infrastructure (roads, communication, gas, water, etc). Besides, economic development also offers abundant business opportunities, which can be explored by entrepreneurs from business entities which operate in the country (general procurement, business solutions, employee outsourcing, etc), or from the high-income population of Malaysia (ride-sharing applications, smartphone entertainment applications, online shopping, etc).

The economic development of Malaysia is like a double-edged sword for entrepreneurial activity. Economic development has created numerous employment opportunities (coupled with high wages), which have attracted more Malaysians to work as professionals rather than build their own businesses (Hamidon 2014). On the other hand, the condition has created more 'qualified' entrepreneurs, which tend to focus on particular business opportunities and try to improve them (to earn more money or become independent), rather than accepting any business opportunities out of necessity, which Xavier et al. (2014) say correlates with the reduction of business discontinuation and the steady growth of established business ownership.

The main restrictive components of the entrepreneurial ecosystem unexpectedly come from internal factors rather than economic factors. Contrary to popular belief, government policies, entrepreneurship education and training, as well as knowledge and skills for start-ups, are the main restrictive components of the entrepreneurial ecosystem in Malaysia. The findings on the restrictive components of the entrepreneurial ecosystem are quite ironic, especially for the component of government policy. The policy created by the government to stimulate 
entrepreneurial activity has, in turn, become one of the restrictive factors in the ecosystem. Further analysis reveals that the primary concerns of Malaysian entrepreneurs on entrepreneurship policy are related to a policy which discouraged equal opportunities for new firms in public procurement, the long period of waiting for business permits, and the excruciating bureaucracy for new and growing firms (Xavier et al., 2014).

Further attention also needs to be paid to entrepreneurship education. Malaysian entrepreneurs feel that educational institutions do not prepare them to acquire the appropriate knowledge on starting a new business, so they need to obtain more knowledge, through vocational, professional and continuing education (Abdullah, 2009; Xavier et al., 2014). This factor also correlates with the other restrictive component of the ecosystem, namely, knowledge and skills for start-ups. Because they have had minimum exposure to entrepreneurship knowledge from the education system, there are many people who feel they are unable to start and manage a business, spot good business opportunities, or organise resources for a business (Xavier et al., 2014).

Ács and Szerb (2012) introduced the Global Entrepreneurship Index (GEI), which measures the health of entrepreneurship ecosystems. The GEI defines entrepreneurship as a multifaceted phenomenon, and this phenomenon can be described by a composite index. The GEI is comprised of three main building blocks, namely, entrepreneurial attitudes, entrepreneurial abilities, and entrepreneurial aspirations (Ács, Szerb, Lafuente, Lloyd, 2018). Entrepreneurial attitudes measure how a country thinks about entrepreneurship. Entrepreneurial abilities are related to the ability and skills possessed by entrepreneurs in a country. Finally, entrepreneurial aspirations measure the real aspirations and the vision of entrepreneurs in a country for their business. These three building blocks stand on 14 pillars, each of which includes individual and institutional variables, as depicted in Table 1.

Table 1. Description of GEI pillars

\begin{tabular}{|c|c|c|}
\hline Sub-Indexes & Pillar Name & Variables \\
\hline \multirow[t]{5}{*}{$\begin{array}{l}\text { Entrepreneurial } \\
\text { attitudes }\end{array}$} & Opportunity Perception & $\begin{array}{l}\text { 1. Opportunity Recognition } \\
\text { 2. Freedom and Property: } \\
\text { - Economic freedom } \\
\text { - Property rights }\end{array}$ \\
\hline & Start-up Skills & $\begin{array}{l}\text { 1. Skill perception } \\
\text { 2. Education }\end{array}$ \\
\hline & Risk Acceptance & $\begin{array}{l}\text { 1. Risk perception } \\
\text { 2. Country risk }\end{array}$ \\
\hline & Networking & $\begin{array}{l}\text { 1. Percentage of the population who personally know an entre- } \\
\text { preneur who started a business within two years } \\
\text { 2. Connectivity: } \\
\text { - Urbanisation } \\
\text { - Infrastructure }\end{array}$ \\
\hline & Cultural Support & $\begin{array}{l}\text { 1. The average percentage of the population who believe entre- } \\
\text { preneurship is a good career choice } \\
\text { 2. Corruption }\end{array}$ \\
\hline \multirow[t]{4}{*}{$\begin{array}{l}\text { Entrepreneurial } \\
\text { abilities }\end{array}$} & Opportunity Start-up & $\begin{array}{l}\text { 1. Percentage of Total Entrepreneurial Activity (TEA) } \\
\text { 2. Taxation and good governance }\end{array}$ \\
\hline & Technology Absorption & $\begin{array}{l}\text { 1. Technology level } \\
\text { 2. Technology absorption }\end{array}$ \\
\hline & Human Capital & $\begin{array}{l}\text { 1. Educational level } \\
\text { 2. Labour freedom and staff training }\end{array}$ \\
\hline & Competition & $\begin{array}{l}\text { 1. The percentage of TEAs which only have a few competitors } \\
\text { that offer the same product or service } \\
\text { 2. Market dominance and regulation }\end{array}$ \\
\hline
\end{tabular}




\begin{tabular}{|c|c|c|}
\hline Sub-Indexes & Pillar Name & Variables \\
\hline \multirow[t]{5}{*}{$\begin{array}{l}\text { Entrepreneurial } \\
\text { aspirations }\end{array}$} & Product Innovation & $\begin{array}{l}\text { 1. The potential to create a new product or to imitate existing } \\
\text { products. } \\
\text { 2. Transfer of technology }\end{array}$ \\
\hline & Process Innovation & $\begin{array}{l}\text { 1. Percentage of businesses of which the principal technology is } \\
\text { less than five years old } \\
\text { 2. R\&D percentage of GDP (Gross Domestic Expenditure on } \\
\text { Research and Development - GERD) }\end{array}$ \\
\hline & High Growth & $\begin{array}{l}\text { 1. Gazelle } \\
\text { 2. Business strategy and venture capital financing }\end{array}$ \\
\hline & Internationalisation & $\begin{array}{l}\text { 1. Exports } \\
\text { 2. The country's economic complexity }\end{array}$ \\
\hline & Risk Capital & $\begin{array}{l}\text { 1. The percentage of informal investors in the population } \\
\text { multiplied by the size of individual investment in other new } \\
\text { start-ups } \\
\text { 2. The depth of the capital market }\end{array}$ \\
\hline
\end{tabular}

Source: Ács et al. (2018).

Unlike the GEM (Global Entrepreneur Monitor), which focused on quantity (the number of establishments), the GEI's point of view is to focus on the quality of innovative entrepreneurship, which could add value to society at large (Acs, Szerb, Autio, 2017). Besides, the GEI recognised both the individual's and the institution's features of entrepreneurship (such as culture, education, regulation and market size), rather than focusing on individual measures as depicted in the GEM (Szerb, Trumbull, 2018). Hence, it can be concluded that the GEI would be beneficial for assessing the entrepreneurship ecosystem in Malaysia.

\section{Methodology}

This paper uses the descriptive statistics method, by exhibiting secondary data from the GEI survey, which covers 101 countries, in the 2006 to 2016 time range. The data used to measure the entrepreneurship ecosystem in Malaysia through the GEI's 14 pillars is comprised of a GEI score and a sub-index score. As is suggested by Szerb and Trumbull (2018), there are three consecutive analyses that need to be performed, in order to obtain a thorough analysis of the GEI. The first analysis is the GEI score of Malaysia. Three steps in the calculation need to be taken in order to obtain a general overview of the entrepreneurship ecosystem in Malaysia. The first step is to calculate the average GEI score of Malaysia, and compare it with other countries' GEI, to see the position of Malaysia among other countries, as well as comparing the individual GEI score of Malaysia with other southeast Asian countries. The second step in the analysis is the analysis of sub-indexes (to the level of 14 pillars). According to the GEI methodology, the value of a sub-index for any country is the arithmetical average of its PFB-adjusted pillars for that sub-index, multiplied by 100 . The maximum value of the sub-indices is 100 , and the potential minimum is 0 , both of which reflect a country's relative position in a particular sub-index (Acs et al., 2017). These sub-indices then analyse deeply at a variable level (institutional and individual) the best 25\% (dark blue), the best 50\% (light blue), the worst 50\% (yellow), and the worst $25 \%$ (red) categorisations.

The second analysis measures Malaysia's GEI performance. The first step in the calculation in this analysis is to observe the GEI score and its sub-index pattern from 2009 to 2016 . This analysis is followed by another sub-index analysis, to observe the components of the sub-indices that caused the decreasing trend in Malaysia's GEI in the same time range. Lastly, we compare Malaysia's entrepreneurship ecosystem with other ASEAN countries within the context of the GEI's 14 pillars. 
The last analysis provides a suggestion for a GEI policy package for Malaysia. In this analysis, we provide a suggestion to improve the entrepreneurship performance of Malaysia, by utilising a method that focuses on the weakest pillar (bottleneck), which is known as the penalty for bottleneck methodology (PFP).

\section{Findings}

\subsection{The GEI of Malaysia}

Based on the world GEI ranking, Malaysia stood at a 'middle rank' among other countries in the world, in terms of its average GEI score from 2012 to 2016. Table 2 depicts an overview of GEI achievement from 95 countries, which describes the GDP per capita of each country, as well as the Global Competitive Index classification, where 1 indicates resource-driven economies, 2 indicates efficiency-driven economies, and 3 indicates innovation-driven economies. Malaysia (highlighted yellow) has the seventh-highest GEI score among Asian countries. This finding is quite surprising, since Malaysia, in turn, has the leading GEI score among developing economies in Asia (highlighted blue) and even almost matches China.

Table 2. Average GEI score from 2012 to 2016

\begin{tabular}{|c|c|c|c|c|c|c|c|c|c|c|c|c|c|c|}
\hline Rank & Country & $\begin{array}{l}\text { GDP per } \\
\text { capita }\end{array}$ & GEI & DEV. & Rank & Country & $\begin{array}{l}\text { GDP } \\
\text { per } \\
\text { capita }\end{array}$ & GEI & DEV. & Rank & Country & $\begin{array}{l}\text { GDP per } \\
\text { capita }\end{array}$ & GEI & DEV. \\
\hline 1 & United States & 51.884 & 82,5 & 3 & 33 & Puerto Rico & 33.844 & 44,6 & 3 & 65 & India & 5.578 & 26,3 & 1 \\
\hline 2 & Switzerland & 56.395 & 78,9 & 3 & 34 & United Arab Emirate & 67.133 & 44,6 & 3 & 66 & Georgia & 9.008 & 25,3 & 2 \\
\hline 3 & Canada & 42.838 & 78,3 & 3 & 35 & Slovakia & 27.489 & 42,8 & 3 & 67 & Trinidad \& Tobago & 31.592 & 25,3 & 2 \\
\hline 4 & Australia & 43.881 & 74,9 & 3 & 36 & Latvia & 22.298 & 42,3 & 2 & 68 & Russia & 24.732 & 24,7 & 2 \\
\hline 5 & Sweden & 44.576 & 74,7 & 3 & 37 & Czech Republic & 28.380 & 40,4 & 3 & 69 & Egypt & 10.079 & 24,2 & 2 \\
\hline 6 & Denmark & 44.709 & 73,7 & 3 & 38 & Saudi Arabia & 50.458 & 40,2 & 2 & 70 & Philippines & 6.589 & 23,9 & 1 \\
\hline 7 & United Kingdom & 37.840 & 72,2 & 3 & 39 & Hungary & 23.946 & 39,4 & 2 & 71 & Argentina & 19.017 & 23,8 & 2 \\
\hline 8 & Ireland & 52.558 & 70,3 & 3 & 40 & Tunisia & 10.577 & 38,8 & 2 & 72 & Iran & 16.184 & 22,5 & 2 \\
\hline 9 & Netherlands & 45.951 & 69,2 & 3 & 41 & Colombia & 12.592 & 38,3 & 2 & 73 & Ghana & 3.720 & 22,5 & 1 \\
\hline 10 & Finland & 39.355 & 68,1 & 3 & 42 & Italy & 34.452 & 38,1 & 3 & 74 & Algeria & 13.207 & 22,2 & 1 \\
\hline 11 & Hong Kong & 54.279 & 67,3 & 3 & 43 & Jordan & 8.390 & 36,5 & 2 & 75 & Vietnam & 5.386 & 22,2 & 1 \\
\hline 12 & France & 37.575 & 65,2 & 3 & 44 & China & 12.765 & 35,9 & 2 & 76 & Nigeria & 5.409 & 22,0 & 1 \\
\hline 13 & Austria & 44.210 & 65,2 & 3 & 45 & Greece & 24.092 & 35,9 & 3 & 77 & Jamaica & 8.090 & 21,7 & 2 \\
\hline 14 & Germany & 43.402 & 64,2 & 3 & 46 & Malaysia & 24.132 & 35,5 & 2 & 78 & Bolivia & 6.325 & 21,4 & 1 \\
\hline 15 & Belgium & 41.216 & 63,3 & 3 & 47 & Romania & 19.376 & 35,0 & 2 & 79 & Indonesia & 10.195 & 21,1 & 2 \\
\hline 16 & Taiwan & 37.832 & 63,0 & 3 & 48 & Botswana & 15.271 & 34,3 & 1 & 80 & El Salvador & 7.743 & 20,7 & 2 \\
\hline 17 & Israel & 31.676 & 61,1 & 3 & 49 & Uruguay & 19.491 & 34,1 & 2 & 81 & Bosnia and Herzego & 10.224 & 20,7 & 2 \\
\hline 18 & Chile & 22.160 & 59,0 & 2 & 50 & Barbados & 15.355 & 34,0 & 2 & 82 & Ecuador & 10.630 & 20,5 & 2 \\
\hline 19 & Luxembourg & 94.277 & 58,5 & 3 & 51 & South Africa & 12.385 & 33,4 & 2 & 83 & Brazil & 14.922 & 20,4 & 2 \\
\hline 20 & Norway & 63.173 & 58,2 & 3 & 52 & Croatia & 20.529 & 32,3 & 2 & 84 & Zambia & 3.543 & 20,3 & 1 \\
\hline 21 & Estonia & 26.772 & 56,0 & 3 & 53 & Costa Rica & 14.135 & 31,5 & 2 & 85 & Senegal & 2.297 & 19,7 & 1 \\
\hline 22 & Qatar & 119.538 & 55,4 & 3 & 54 & Lebanon & 13.031 & 31,0 & 2 & 86 & Guatemala & 7.203 & 18,4 & 2 \\
\hline 23 & Korea & 33.372 & 53,6 & 3 & 55 & Kazakhstan & 23.509 & 30,0 & 1 & 87 & Suriname & 15.371 & 17,9 & 2 \\
\hline 24 & Slovenia & 28.592 & 52,9 & 3 & 56 & Belize & 7.941 & 29,8 & 2 & 88 & Pakistan & 4.367 & 17,5 & 1 \\
\hline 25 & Singapore & 78.294 & 52,1 & 3 & 57 & Namibia & 9.113 & 29,4 & 2 & 89 & Libya & & 17,2 & 1 \\
\hline 26 & Japan & 36.946 & 49,4 & 3 & 58 & Macedonia & 12.310 & 29,1 & 2 & 90 & Malawi & 1.051 & 16,6 & 1 \\
\hline 27 & Cyprus & 31.196 & 48,0 & 3 & 59 & Morocco & 7.276 & 28,2 & 2 & 91 & Ethiopia & 1.231 & 15,5 & 1 \\
\hline 28 & Portugal & 26.208 & 47,0 & 3 & 60 & Thailand & 15.000 & 27,7 & 2 & 92 & Cameroon & 740 & 15,3 & 1 \\
\hline 29 & Poland & 24.484 & 46,9 & 2 & 61 & Peru & 11.552 & 27,4 & 2 & 93 & Uganda & 1.646 & 13,9 & 1 \\
\hline 30 & Lithuania & 25.150 & 46,4 & 2 & 62 & Mexico & 16.520 & 26,6 & 2 & 94 & Angola & 6.148 & 13,8 & 1 \\
\hline 31 & Spain & 31.691 & 45,6 & 3 & 63 & Bulgaria & 17.355 & 26,5 & 2 & 95 & Burkina Faso & 1.560 & 12,5 & 1 \\
\hline 32 & Turkey & 21.871 & 45,0 & 2 & 64 & Panama & 19.824 & 26,4 & 2 & & & & & \\
\hline
\end{tabular}

Source: compiled by the author.

From a regional perspective, Malaysia belongs to the southeast Asia region, and there are four other countries in the region which participated in the GEI survey, namely, Singapore, Indonesia, Thailand and the Philippines. Further analysis of the GEI sub-indices reveals that the GEI score of Malaysia is among the top in the ASEAN region. As is depicted in Table 3, Malaysia had the second-largest GEI score after Singapore in 2014. Malaysia's GEI score is mostly affected by entrepreneurial abilities in the sub-index score, which is the highest, followed by entrepreneurial attitudes, and entrepreneurial aspirations. 
Table 3. Malaysia's GEI score compared to other southeast Asian countries (2014)

\begin{tabular}{|l|l|l|l|l|l|}
\hline \multicolumn{1}{|c|}{ Country } & \multicolumn{1}{|c|}{$\begin{array}{c}\text { GDP Per Capita } \\
\text { (PPP-International \$) }\end{array}$} & GEI & $\begin{array}{c}\text { Entrepreneurial } \\
\text { attitudes }\end{array}$ & $\begin{array}{c}\text { Entrepreneurial } \\
\text { abilities }\end{array}$ & $\begin{array}{c}\text { Entrepreneurial } \\
\text { aspirations }\end{array}$ \\
\hline Singapore & 80,305 & 51.9 & 37.6 & 58.2 & 60.0 \\
\hline Malaysia & $\mathbf{2 4 , 1 9 6}$ & $\mathbf{3 4 . 6}$ & $\mathbf{3 8 . 2}$ & $\mathbf{3 9 . 0}$ & $\mathbf{2 6 . 6}$ \\
\hline Thailand & 14,853 & 28.4 & 28.6 & 30.5 & 26.1 \\
\hline Philippines & 6,586 & 24.1 & 28.8 & 22.3 & 21.0 \\
\hline Indonesia & 10,003 & 21.9 & 30.7 & 20.2 & 14.9 \\
\hline
\end{tabular}

Source: compiled by the author.

As can be seen from Table 4, the analysis of the sub-indices (to the level of 14 pillars) has revealed some interesting findings. Seven out of the 14 pillars can be categorised as low performance with low scores (highlighted in red), namely, start-up skills, cultural support, technology absorption, product innovation, high growth, internationalisation, and risk capital.

Table 4. Malaysia's GEI sub-index score details

\begin{tabular}{|c|c|c|c|c|c|}
\hline \multicolumn{6}{|c|}{ Components of Entrepreneurial Attitudes Sub-index (normalized scores) } \\
\hline & Opportunity perception & Start-up skills & Risk acceptance & Networking & Cultural support \\
\hline Malaysia & 0,46 & 0,25 & 0,55 & 0,68 & 0,23 \\
\hline $33 \%$ percentile & 0,32 & 0,31 & 0,26 & 0,36 & 0,29 \\
\hline $67 \%$ percentile & 0,54 & 0,58 & 0,63 & 0,53 & 0,57 \\
\hline & & & & & \\
\hline & & & & & \\
\hline \multicolumn{6}{|c|}{ Components of Entrepreneurial Abilities Sub-index (normalized scores) } \\
\hline & Opportunity startup & Technology absorptior & Human capital & Competition & \\
\hline Malaysia & 0,61 & 0,09 & 0,69 & 0,56 & \\
\hline $33 \%$ percentile & 0,30 & 0,29 & 0,33 & 0,31 & \\
\hline $67 \%$ percentile & 0,60 & 0,60 & 0,54 & 0,54 & \\
\hline \multicolumn{6}{|c|}{ Components of Entrepreneurial Aspirations Sub-index (normalized scores) } \\
\hline & Product innovation & Process innovation & High growth & Internationalization & Risk capital \\
\hline Malaysia & 0,24 & 0,72 & 0,19 & 0,32 & 0,22 \\
\hline $33 \%$ percentile & 0,31 & 0,30 & 0,28 & 0,32 & 0,28 \\
\hline $67 \%$ percentile & 0,54 & 0,61 & 0,62 & 0,57 & 0,60 \\
\hline
\end{tabular}

Source: compiled by the author.

The low score for the level of start-up skills in Malaysia is consistent with the findings by Abdullah (2009) and Xavier (2014), in which Malaysia's educational institutions do not provide students with appropriate entrepreneurship training; thus, it directly contributes to the low score for start-up skills, and indirectly affects cultural support and high growth. The low level of technology absorption and product innovation may reflect the unwillingness of Malaysia to develop its own technology, since it is already satisfied with the available technology (Abdullah, 2009). The low score for internationalisation and risk capital might be caused by the low level of willingness in Malaysia to invest in start-ups, since the 'financial security' mindset is deeply planted in society (Hamidon, 2014), and they perceive investing in a start-up as too risky, thus many start-ups struggle to find investors and expand their presence internationally (the cost of 'going international' is high). Despite the existence of low score components, there are two average-score pillars (highlighted in yellow), namely, opportunity perception and risk acceptance, as well as five high-score pillars (highlighted in green), namely, networking, opportunity start-up, human capital, competition, and process innovation. 
Moreover, a deeper analysis of the entrepreneurial profile at the variable level (institutional and individual) reveals other important findings. Table 4 depicts the categorisation of the items based on the best $25 \%$ (dark blue), the best $50 \%$ (light blue), the worst $50 \%$ (yellow), and the worst $25 \%$ (red), from all countries for the 14 pillars, institutional variables, and individual variables. Because the 14 pillar scores in Table 4 are consistent with Table 3, the next analysis will discuss the institutional variables and individual variables score.

Table 5. Malaysia's entrepreneurial profile at the variable level (2012-2016 averages)

\begin{tabular}{|c|c|c|c|c|c|c|}
\hline & \multicolumn{2}{|l|}{ PILLARS } & \multicolumn{2}{|c|}{$\begin{array}{l}\text { INSTITUTIONAL } \\
\text { VARIABLES }\end{array}$} & \multicolumn{2}{|c|}{ INDIVIDUAL VARIABLES } \\
\hline \multirow{6}{*}{ 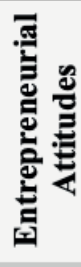 } & Opportunity Perception & 0.46 & Freedom & 0.64 & Opportunity Recognition & 0.52 \\
\hline & Start-up skills & 0.25 & Education & 0.57 & Skill Perception & 0.32 \\
\hline & Risk Acceptance & 0.55 & Country Risk & 0.61 & Risk Perception & 0.67 \\
\hline & Networking & 0.68 & Connectivity & 0.74 & Know Entrepreneurs & 0.63 \\
\hline & Cultural Support & 0.23 & Corruption & 0.56 & Career Status & 0.23 \\
\hline & Entrepreneurial Attitudes & 37.1 & & & & \\
\hline \multirow{5}{*}{ 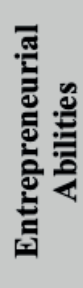 } & Opportunity Startup & 0.61 & Governance & 0.67 & Opportunity Motivation & 0.92 \\
\hline & Technology Absorption & 0.09 & $\begin{array}{l}\text { Technology } \\
\text { Absorption }\end{array}$ & 0.75 & Technology Level & 0.20 \\
\hline & Human Capital & 0.69 & Labour Market & 0.86 & Educational Level & 0.67 \\
\hline & Competition & 0.56 & $\begin{array}{l}\text { Competitiveness and } \\
\text { Regulation }\end{array}$ & 0.79 & Competitors & 0.49 \\
\hline & Entrepreneurial Abilities & 39.9 & & & & \\
\hline \multirow{7}{*}{ 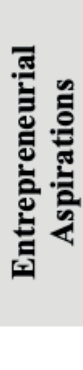 } & Product Innovation & 0.24 & Technology Transfer & 0.79 & New Product & 0.33 \\
\hline & Process Innovation & 0.72 & Science & 0.69 & New Technology & 0.87 \\
\hline & High Growth & 0.19 & Finance and strategy & 0.93 & Gazelle & 0.19 \\
\hline & Internationalization & 0.32 & Economic complexity & 0.69 & Export & 0.44 \\
\hline & Risk Capital & 0.22 & $\begin{array}{l}\text { Depth of Capital } \\
\text { Market }\end{array}$ & 0.92 & Informal Investment & 0.31 \\
\hline & $\begin{array}{l}\text { Entrepreneurial } \\
\text { Aspirations }\end{array}$ & 29.6 & & & & \\
\hline & GEI & 35.5 & Institutional & 0.73 & Individual & 0.49 \\
\hline
\end{tabular}

Source: compiled by the author.

As can be seen from Table 5, there are only five institutional variables in Malaysia which are among the best countries (25\%), namely, the labour market, competitiveness and regulation, technology transfer, finance and strategy, and the depth of the capital market. Another seven variables are among the top 50\% (freedom, connectivity, corruption, governance, technology absorption, science, and economic complexity), and two variables are among the worst $50 \%$ (education and country risk). The reason behind the low score of the education factor should be related to the findings of Abdullah (2009) and Xavier et al. (2014) regarding the lack of attention to entrepreneurship-related education in the educational system. Besides, Malaysia is well known for heavy intervention by the government in the financial market, which often discourages foreign businesses that operate in the country (Ahmed, Julian, Majar, 2006). The intervention may cause exchange rate risk or fund transfer prevention, which becomes a parameter of the variable. Nevertheless, the overall situation of institutional variables is better than the individual variables.

Based on the analysis, there are only two variables which are among the best $25 \%$ countries (opportunity motivation, and new technology), and three variables which are among the best $50 \%$ countries (risk perception, knowing an entrepreneur, and educational level). On the other hand, variables from the catego- 
ries of the worst $50 \%$ and the worst $25 \%$ are the dominant variables. According to the data, there are three variables that are among the worst $50 \%$ countries (opportunity recognition, competitors, and exports), and seven variables that are among the worst $25 \%$ countries (skills perception, career status, technology level, new products, gazelle, and informal investment). These findings indicate that some of the variables of the entrepreneur's attitude, abilities and aspirations are relatively shallow compared to other countries. As was previously mentioned by Hamidon (2014), the economic development of Malaysia has created numerous employment opportunities that have attracted more Malaysians to work as professionals rather than build their own businesses. The direct result of this phenomenon is the lower participation of the workforce in the entrepreneurial sector, which causes a lower rate of innovation, discouraging investment in start-ups, and a sceptical view of the profession of an entrepreneur.

\subsection{The GEI performance of Malaysia (2009-2016)}

Based on the time series analysis of Malaysia's GEI score from 2009 to 2016, the GEI score fluctuates quite a lot. The GEI score of Malaysia exhibits an increasing pattern for all sub-indices from 2010 to 2012, followed by a steady decline from 2012 to 2016, as is depicted in Figure 1. The short increase in GEI score is caused by the direct effect of economic recovery after the Global Financial Crisis of 2008, which stimulated the real estate sector to grow and indirectly stimulate entrepreneurial activity in the country (Ahmad, Xavier, 2011). The steady decline of the GEI score could be the indirect result of declining good governance in Malaysia, where during the decade, Malaysia was rocked by widespread corruption and declining government effectiveness, which eventually led to the 1MDB mega corruption scandal (Hazis, 2018). Although the GEI score pattern from 2012 to 2016 is decreasing, there is a slight increase in the entrepreneurial aspiration score from 2015 to 2016. Besides, it appears that entrepreneurial abilities are the most dominant sub-indices of the GEI for Malaysia.

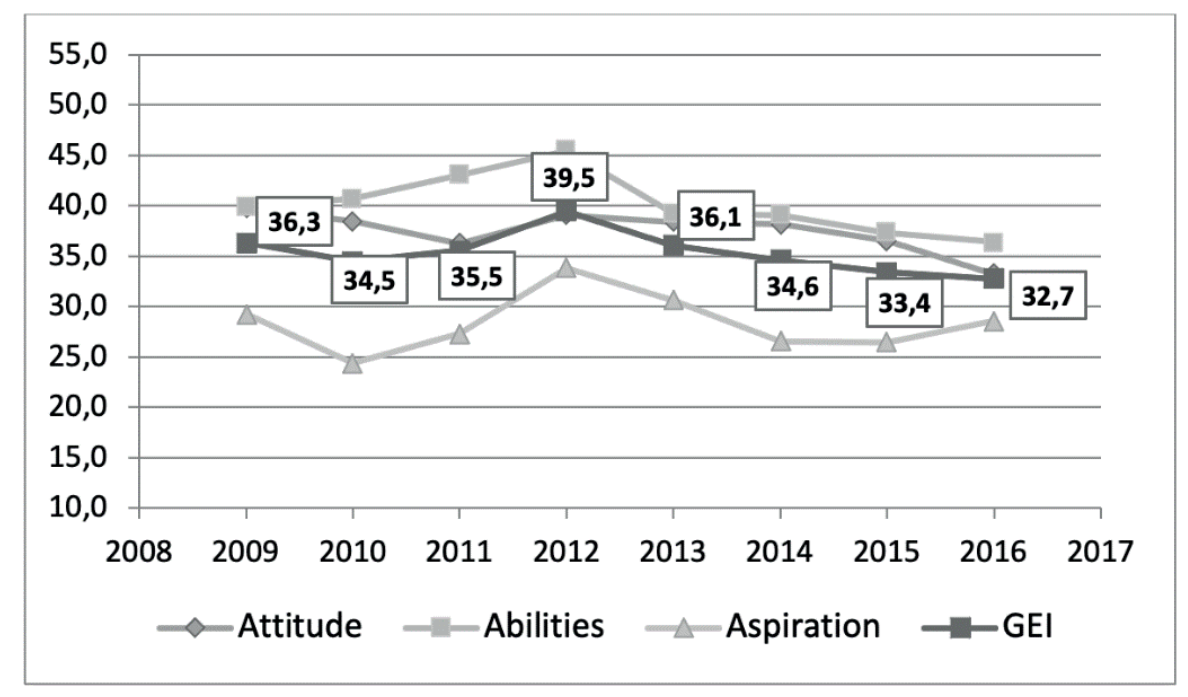

Figure 1. Malaysia's GEI score and its sub-indices (2009-2016)

Source: compiled by the author.

The next question is, what are the components of the sub-indices which caused the decreasing trend in Malaysia's GEI? In order to answer this question, further observation of the 14 pillars of GEI is needed. Figure 2 depicts Malaysia's 14 pillars of GEI from 2012 to 2016, and the number of the pillar with the decreasing score is quite significant. 


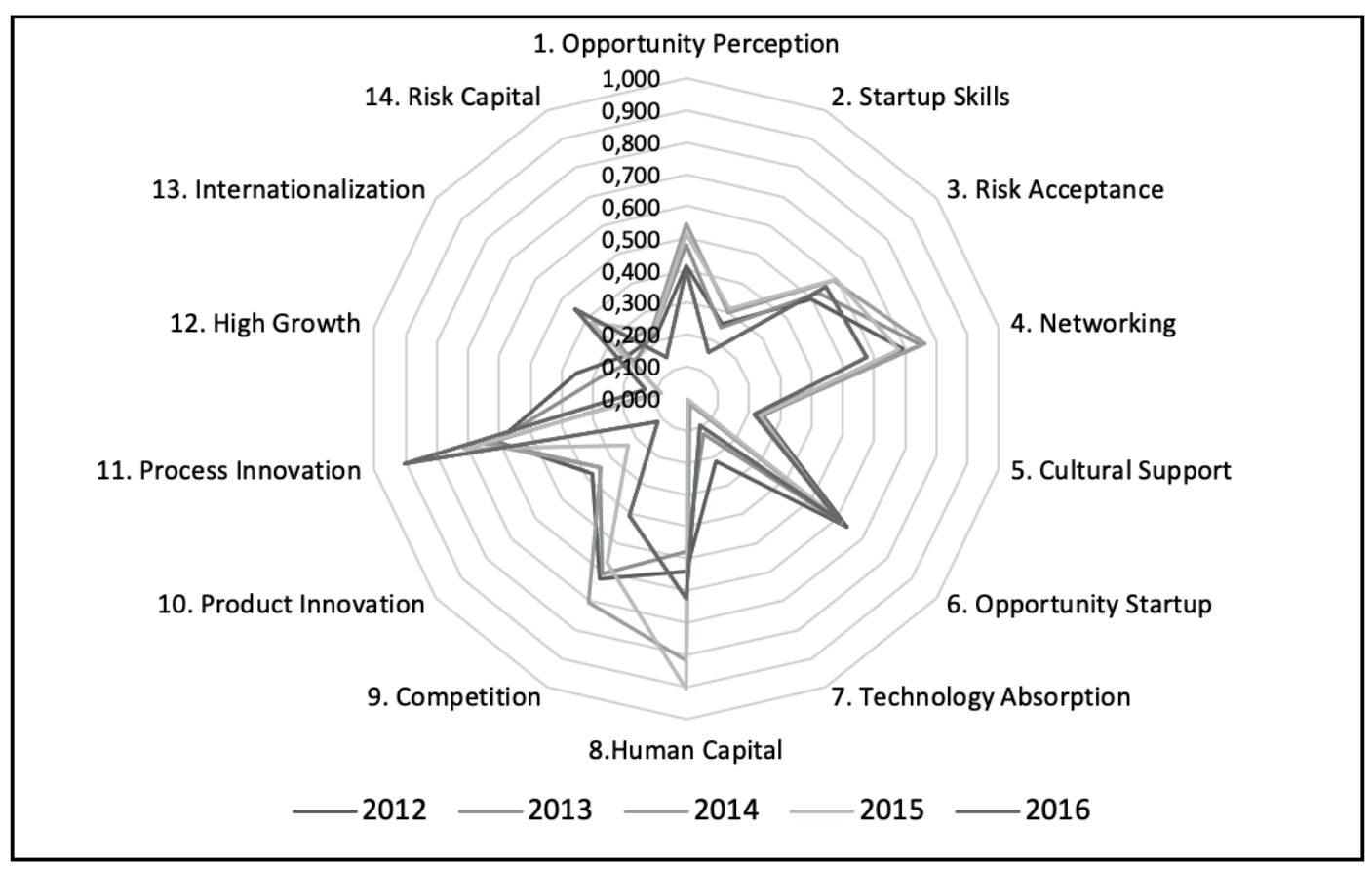

Figure 2. Malaysia's 14 pillars of GEI (2012-2016)

Source: compiled by the author.

Almost all the pillars exhibit a decreasing pattern, three pillars (opportunity perception, start-up skills, and risk acceptance) which previously exhibited an increasing pattern (from 2012 to 2015) even decreased in 2016. Other patterns that can be identified are six fluctuating pillars but with a decreasing trend, namely, networking, cultural support, opportunity start-up, human capital, competition, and risk capital. Finally, there are three pillars which exhibit a continuously decreasing trend during the time range, namely, technology absorption, product innovation, and high growth. Despite the volatility of the score, it can be concluded that there are two dominant pillars that are unique to Malaysia, which are human capital and process innovation. Thanks to the significant economic development that started two decades ago, the quality of manpower in the country has increased significantly. Moreover, because the majority of Malaysians choose to work in a large corporation rather than start their own business, the innovations that emerge in Malaysia are predominantly on the side of improving the existing process, rather than inventing a new product.

After examining the 'internal health' of the Malaysian entrepreneurship ecosystem, it would be beneficial to compare Malaysia's entrepreneurship ecosystem with its ASEAN counterparts within the context of the GEI's 14 pillars. As is depicted in Figure 3, the scores of Malaysia's GEI pillars are basically quite a lot better than its ASEAN counterparts, except for Singapore.

Based on the data, it can be seen that Malaysia is outpacing Indonesia, the Philippines, and Thailand for eight types of pillars, but there are six types of pillar where it still falls behind. It should be noted that of these six pillars, there are three pillars on which Malaysia has been totally left behind by its ASEAN counterparts, namely, start-up skills, cultural support, and product innovation. These so-called 'bottlenecks' could be addressed by applying particular policies, such as employing an entrepreneurial education curriculum in formal education institutions, while supporting non-formal training for the entrepreneur (increasing start-up skills and product innovation), or conducting a campaign on the importance of entrepreneurship in society (increasing cultural support). 


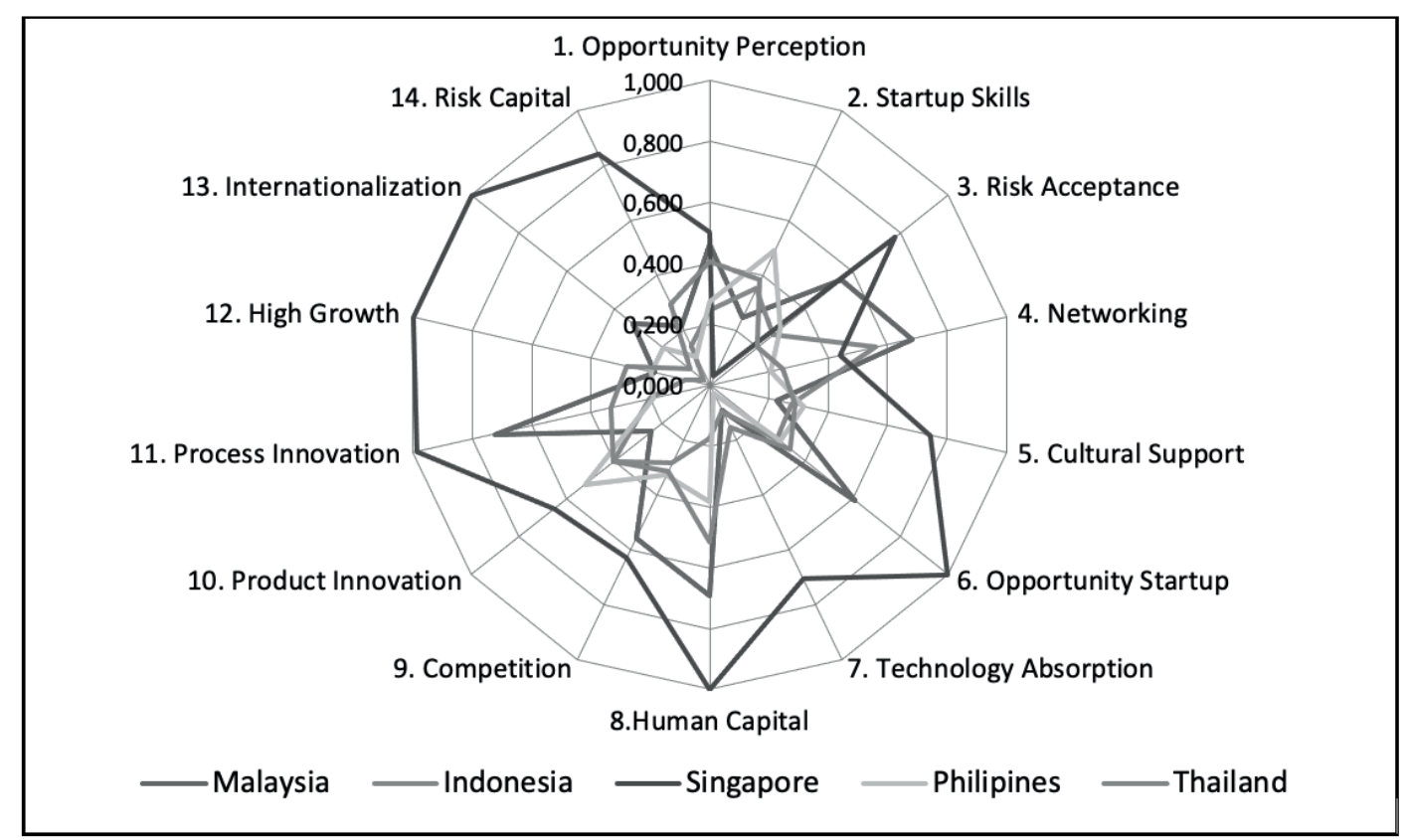

Figure 3. A comparison of the 14 pillars between Malaysia and its ASEAN counterparts (based on the 2012-2016 average)

Source: compiled by the author.

\subsection{The GEI policy package for Malaysia}

In order to improve Malaysia's entrepreneurship performance, there is a method that can be utilised that focuses on the weakest pillar (bottleneck), which is known as the penalty for bottleneck methodology (PFP). The basic assumption of PFP methodology is that the overall entrepreneurship performance will depend on the bad-performing pillar. In other words, if the bottlenecks are improved, the country's GEI score will be improved as well (Szerb, Acs, Autio, 2014). Table 6 provides a concise explanation of the method.

In order to increase Malaysia's GEI by at least $10 \%$, there are seven pillars that need to be improved (highlighted in dark green and light green), namely, technology absorption (a 24\% increase), high growth (a $15 \%$ increase), risk capital (an 11\% increase), cultural support (a 10\% increase), product innovation (a 9\% increase), start-up skills (an 8\% increase), and internationalisation (a 1\% increase). Besides, each pillar has its own proportion of new effort, as a guide to policymakers to focus their improvements on a more specific area. In the case of Malaysia, more attention and effort should be given to the technology absorption pillar (31\%) and high growth (19\%), followed by risk capital (14\%), cultural support (13\%), product innovation $(12 \%)$, start-up skills $(10 \%)$, and internationalisation (1\%).

The technology absorption pillar is defined as business activity in the technology sector, combined with the country's capability for technology absorption. In order to improve this pillar, Malaysia should encourage and provide support to entrepreneurs who engage in business activity in the technology sector. The Malaysian government has long invested in the heavy industrialisation of the country, including encouraging investment in technology-related industries, such as electronic appliances and semi-conductors. Nevertheless, their production is focused on satisfying export demand, and the majority of manufacturers are also foreign investors, thus, the 'organic' growth of the technology sector rarely happens in Malaysia. Besides, due to confidentiality on how to manufacture a product, the transfer of technology from larger to smaller enterprises would not exist (Abdullah and Muhammad, 2008). In order to address these issues, the Malaysian government should focus on nurturing home-grown 'tech entrepreneurs', by creating policies which benefit them, such as promoting local 
technology, promoting prominent home-grown 'tech entrepreneurs' at national and international events, tax holidays, a less complicated business permit application process, and business training. The transfer of technology (ToT) is essential to obtain new technical knowledge, which will benefit local entrepreneurs. The government has the power to impose a ToT scheme on every large corporation that operates in the country. By conducting the scheme, local entrepreneurs will absorb knowledge and produce their own products/services.

Table 6. The simulation of GEI optimum policy allocation

\begin{tabular}{|c|c|c|}
\hline Target GEI Change & 0,10 & \\
\hline Pillar & Required Increase in Pillar & Percentage of total new effort \\
\hline Opportunity Perception & 0,00 & $0 \%$ \\
\hline Start-up Skills & 0,08 & $10 \%$ \\
\hline Risk Acceptance & 0,00 & $0 \%$ \\
\hline Networking & 0,00 & $0 \%$ \\
\hline Cultural Support & $\mathbf{0 , 1 0}$ & $13 \%$ \\
\hline Opportunity Startup & 0,00 & $0 \%$ \\
\hline Technology Absorption & 0,24 & $31 \%$ \\
\hline Human Capital & 0,00 & $0 \%$ \\
\hline Competition & 0,00 & $0 \%$ \\
\hline Product Innovation & 0,09 & $12 \%$ \\
\hline Process Innovation & 0,00 & $0 \%$ \\
\hline High Growth & 0,15 & $19 \%$ \\
\hline Internationalisation & $\mathbf{0 , 0 1}$ & $1 \%$ \\
\hline Risk Capital & 0,11 & $14 \%$ \\
\hline
\end{tabular}

Source: compiled by the author.

The second pillar that needs to be improved is high growth. High growth is the combined measure of high-growth businesses that intend to employ ten people, and plan to grow over 50\% in five years (Gazelle). In order to stimulate growth, the government needs to enact policies which benefit bank lenders, by providing a fair interest rate and a longer time to pay back the money.

The third pillar that requires a similar improvement is risk capital. Risk capital is the availability of capital from both individual and institutional investors. The government could enact policies that could reduce barriers in the market to providing venture capital or private equity financing, by relaxed regulatory requirements for private equity or venture capital that is to be invested in entrepreneurial activities.

Cultural support is the next pillar that requires attention. Cultural support reflects how a country's population perceives entrepreneurs in terms of their status and career choices, as well as the level of corruption which affects their view. In order to improve the pillar, the Malaysian government needs to establish clean governance, by combatting corruption, encouraging an entrepreneurship culture by integrating it into the school curriculum, and providing greater attention in entrepreneurship statistics data collection, such as growth, numbers and effects on GDP.

The next pillars that need to be improved are product innovation, followed by start-up skills. These pillars require a similar solution to improve, whereas the government should enact regulations to encourage entrepreneurial education in schools, which would lead to more product innovation and leverage start-up skills, as well as fostering partnerships with research groups in universities to stimulate the creation of innovative products.

Finally, in order to improve the internationalisation pillar, the government should support the global outreach of Malaysian entrepreneurs, by providing subsidies for the international exhibitions they want to join, promoting their products overseas by using Malaysian embassies as the channel, and connecting local entrepreneurs with foreign investors. 


\section{Conclusions}

The GEI could become a great solution for identifying the entrepreneurial ecosystem in Malaysia. The GEI offers an effective PFP methodology to identify areas that need to be improved in a comprehensive manner. The analysis reveals that Malaysia has two strong pillars that are unique to the country, namely 'human capital' and 'process innovation'. Thanks to the significant economic development which started two decades ago, the quality of manpower in the country has increased significantly. Moreover, because most Malaysians choose to work in a large corporation rather than start their own businesses, the innovation that emerges in Malaysia is predominantly on the side of improving an existing process, rather than inventing a new product.

However, there are seven other pillars that did not perform well, namely, the technology absorption pillar, high growth, risk capital, cultural support, product innovation, start-up skills, and internationalisation. In order to improve these areas, the Malaysian government should enact 'supportive regulation' for entrepreneurs, such as promoting entrepreneurs in external events, tax holidays, a less complicated business permit application process, ease of access to bank loans, and business training. Finally, the author hopes that the future of entrepreneurship in Malaysia will be bright, since the new regime, in turn, is paying more attention to the entrepreneurial sector, by reactivating the defunct Ministry of Entrepreneur Development (MED) after its closure in 2007, and the GEI could serve as an ideal policy guide for the MED.

\section{References}

Abdul, S., Fazilah, M. (2002). Bumiputras in the Corporate Sector: Three Decades of Performance 1970-2000. Kuala Lumpur: CEDER University of Malaya.

Abdullah, S., Muhammad, A. (2008). The development of entrepreneurship in Malaysia: State-led initiatives. Asian Journal of Technology Innovation, Vol. 16(1), p. 101-116.

Abdullah, S. (2009). The transformation from entrepreneurship to technology entrepreneurship development in Malaysia: State-led initiatives. Journal of Chinese Entrepreneurship, Vol. 1(3), p. 240-247.

Ahmad, S. Z., Xavier, S. R. (2012). Entrepreneurial environments and growth: evidence from Malaysia GEM data. Journal of Chinese Entrepreneurship.

Ács, Z. J., Szerb, L. (2012). Global Entrepreneurship and Development Index 2012. Cheltenham: Edward Elgar Publishing.

Ács, Z. J., Szerb, L., Lloyd, A. (2017). Global Entrepreneurship and Development Index 2017. Washington DC: CreateSpace Independent Publishing Platform.

Acs, Z. J., Szerb, L., Autio, E. (2017). The Global Entrepreneurship and Development Index. Doi: 10.1007/978-3-31926730-2_2.

Ács, Z. J., Szerb, L., Lafuente, E., Lloyd, A. (2018). Global Entrepreneurship and Development Index 2018. Switzerland: Springer.

Ahmad, S. Z., Xavier, S. R. (2011). Entrepreneurial environments and growth: evidence from Malaysia GEM data. Journal of Chinese Entrepreneurship, Vol. 4(1), p. 50-69.

Ahmed, Z. U., Julian, C. C., Majar, A. J. (2006). Export Incentives and International Entrepreneurship in Malaysian Firms. The International Journal of Entrepreneurship and Innovation, Vol. 7(1), p. 49-57.

Ariffin, A. S., Baqutayan, S. M. S., Mahdzir, A. M. (2020). Enhancing women entrepreneurship development framework: Policy \& institution gap and challenges in the case of Malaysia. Journal of Science, Technology and Innovation Policy, Vol. 6(2), p. 22-33.

Bernama. (2018). Entrepreneur development ministry to train entrepreneurs. New Straits Times. Retrieved from https:// www.nst.com.my/news/nation/2018/09/413848/entrepreneur-development-ministry-train-entrepreneurs

Central Intelligence Agency. (2016). The World Factbook 2016-17. Washington, DC: Central Intelligence Agency.

Department of Statistics Malaysia. (2018). Malaysia Economy 2017. Retrieved from https://www.dosm.gov.my/v1/index.php? $\mathrm{r}=$ column/cthemeByCat\&cat=153\&bul_id=UXFINUwxaUVJNUFqVG5qYmtXaWRRUT09\&menu_id= TE5CRUZCblh4ZTZMODZIbmk2aWRRQT09

Hamidon, S. (2014). The Development of Malay Entrepreneurship in Malaysia. Kuala Lumpur: ITBM.

Hazis, F. S. (2018). Malaysia in 2017: Strong Economic Growth amidst Intense Power Struggle. Southeast Asian Affairs, p. 201-218.

International Monetary Fund. (2017). GDP per capita (U.S. Dollars per Capita). Retrieved from https://www.imf.org/ external/datamapper/NGDPDPC@WEO/THA/MYS/SGP/PHL/IDN/BRN 
Isenberg, D. (2011). The Entrepreneurship Ecosystem Strategy as a New Paradigm for Economic Policy: Principles for Cultivating Entrepreneurship. Dublin: Institute of International European Affairs.

Khan, R. A., Liew, M. S., Ghazali, Z. B. (2014). Malaysian Construction Sector and Malaysia Vision 2020: Developed Nation Status. Procedia-Social and Behavioral Sciences, Vol. 109, p. 507-513.

Pennington, J. (2019). Malaysia's economy suffers as political instability continues post GE14. ASEAN Today. Retrieved from https://www.aseantoday.com/2019/01/malaysias-economy-suffers-as-political-instability-continuespost-ge14/

Roundy, P. T., Bradshaw, M., Brockman, B. K. (2018). The emergence of entrepreneurial ecosystems: A complex adaptive systems approach. Journal of Business Research, Vol. 86, p. 1-10.

Szerb, L., Acs, Z. J., Autio, E. (2014). Entrepreneurship measure and entrepreneurship policy in the European Union: The Global Entrepreneurship Index perspective. Paper presented at ATINER, 11 th Annual International Conference on SMEs, Entrepreneurship and Innovation: Management - Marketing - Economic - Social Aspects.

Szerb, L., Trumbull, W. N. (2018). Entrepreneurship development in Russia: is Russia a normal country? An empirical analysis. Journal of Small Business and Enterprise Development, Vol. 25(6), p. 902-929.

The World Bank. (2018). Global GDP Ranking. Retrieved from https://data.worldbank.org/data-catalog/GDP-rankingtable

World Economic Forum. (2018). Global Competitiveness Index 2017-2018. Retrieved from http://reports.weforum. org/global-competitiveness-index-2017-2018/competitiveness-rankings/

Xavier, S. R., Clayton, G. J., Yusof, M., Nor, L. M., Sapuan, D. A. (2014). Entrepeneurship Trends In Malaysia: A National Five Year Longitudinal Study Using GEM Methodology. Kuala Lumpur: University Tun Abdul Razak

\title{
VERSLO EKOSISTEMA MALAIZIJOJE:PASAULINIO VER S L ININKYSTÉS INDEKSOANALIZE்
}

\author{
SaKti Hendra Pramudya \\ Péčo universitetas (Vengrija), BINUS universitetas (Indonezija)
}

\section{Santrauka}

Šiuo tyrimu siekta nustatyti verslumo ekosistemą Malaizijoje, remiantis Pasauliniu verslumo indeksu (PVI). Prieš du dešimtmečius prasidẻjusios reikšmingos ekonominès plètros dẻka darbuotojų darbo kokybẻ šalyje gerokai išaugo. Tačiau pastebima, kad dauguma malaiziečių renkasi darbą didelejje korporacijoje, o ne pradeda savo verslą. Naujovès Malaizijoje daugiausia susijusios su esamo proceso tobulinimu, o ne naujo produkto kūrimu.

Autorius straipsnyje analizuoja verslumo ekosistemą. Tai sudètingas dalyvių, tinklų, institucijų ir sukurtos vertės rinkinys, leidžiantis palaikyti verslumą. Tad vertinant verslininkystės aspektu, šaliai kyla problema, susijusi su verslumo plètra, kurią reikia analizuoti ne tik renkantis konkrečius statistinius duomenis apie verslininkų skaičių, bet ieškant koreliacijų, tinklaveikos. Tarkim, vien iš šalies verslininkų skaičiaus, palyginus su kitų šalių skaičiais, jų plètojamo verslo kokybės, pavyzdžiui, žmogiškojo kapitalo, jo turimų ịūdžių, įdiegtų technologijų nenustatysi. Todèl autorius tyrimui pasirinko su Malaizija palyginti kitas Azijos šalis, taikydamas pasaulinị verslumo indeksą ir atitinkamus kriterijus. Malaizijos, kaip vienos geriausių Azijos šalių ekonomikų, PVI balas 2012-2016 m. buvo ties viduriu (46 vieta iš 96 apklaustų šalių). Atlikta analizė atskleidè, kad Malaizija turi du stiprius šalies ramsčius - žmogiškajji kapitalą ir inovatyvumo gebejjimą. Septyniose srityse, remiantis pasauliniu verslumo indeksu, Malaizijos rodikliai yra silpnesni, tai: nespartus ekonomikos augimas, naujų technologijų diegimas, nesukauptas rizikos kapitalas, menka parama kultūrai, 
nekuriami nauji produktai, mažas skaičius startuolių, nevyksta nuoseklus internacionalizavimas. Siekdama šias sritis patobulinti, Malaizijos vyriausybė turi padėti verslininkams, kurdama įvairių paramos formų paketą. Pavyzdžiui, remti verslininkus jiems vykstant ị svarbias pasaulines parodas, suteikti mokesčių lengvatų ar atidèti mokesčių mokèjimą numatytam terminui, palengvinti verslo leidimo procesą, paprastinti paskolos iš banko gavimą ir rengti verslininkystès mokymus.

PAGRINDINIAI ŽODŽIAI: verslumo ekosistema, pasaulinis verslininkystės indeksas, Malaizija.

JEL KLASIFIKACIJA: L26, O38, R11.

Received: 2021-04-28

Revised: 2021-06-20

Accepted: 2021-09-03 